\title{
ДЕЯКІ АСПЕКТИ СУЧАСНОГО ВИКЛАДАННЯ ДИТЯЧОЇ ХІРУРГІЇ НА ДОДИПЛОМНОМУ РІВНІ У ПІДГОТОВЦІ СІМЕЙНИХ ЛІКАРІВ
}

\author{
П. В. Гощинський
}

ДВНЗ “Тернопільський держсавний медичний університет імені І. Я. Горбачевського МОЗ Украӥни”

\section{SOME ASPECTS OF MODERN TEACHING THE PEDIATRIC SURGERY IN FAMILY DOCTORS TRAINING AT PRE-GRADUATION LEVEL}

\author{
P. V. Hoshchynskyi \\ SHEI "Ternopil State Medical University by I.Ya. Horbachevsky of MPH of Ukraine"
}

\begin{abstract}
У статті наводяться нові технології інтерактивного навчання студентів дитячої хірургії 3 метою підвищення професійного рівня і підготовки їх до роботи сімейним лікарем.
\end{abstract}

The article presents the new technologies of interactive students' teaching of Pediatric Surgery in order to improve professional skills and preparing them family doctors work.

Вступ. Реформування вищої освіти починається 3 оптимізації навчального процесу та активного впровадження кредитно-модульної системи, яка має відповідати міжнародним стандартам. Зрозуміло, що реформування вищої освіти повинно проходити в унісон із реформуванням системи охорони здоров' я, що відбувається в Україні [2]. Спільною метою цих двох процесів є підготовка спеціалістів для первинної медико-санітарної допомоги - лікарів загальної практики/сімейних лікарів. Саме вони стають основною фігурою у наданні медичної допомоги населенню України. Однак поряд із такими базовими дисциплінами, як терапія, хірургія, акушерство та гінекологія, опанування педіатрії і дитячої хірургії в силу специфіки роботи сімейного лікаря стає одним із ключових питань у його підготовці.

Тому викладання дитячої хірургії на додипломному рівні ставить за мету - підготувати майбутніх сімейних лікарів до надання первинної допомоги дітям із хірургічними захворюваннями, травмами i невідкладними станами, навчити їх методів виявлення та інтерпретації симптомів, диференційної діагностики хірургічних захворювань дитячого віку, оскільки близько $40 \%$ дітей з хірургічними захворюваннями спочатку звертаються до лікарів загального профілю і не менший відсоток дітей з хірургічною патологією лікується у відділеннях загального профілю. Таким чином, перед системою вищої медичної освіти постає завдання з підготовки молодих фахівців, що не лише володіють високими теоретичними знаннями за основним фахом, але і здатних опанувати спеціальності, в тому числі і дитячої хірургії, що вимагають додаткової підготовки, швидкого і ефективного реагування на досягнення медичної науки, готових упроваджувати нові технології в практичну охорону здоров’ я і при цьому зберегти і примножити загальнолюдські компетенції $[1,3]$.

Основна частина. На нашу думку, підсумком професійної освіти в сучасних умовах стає компетентність (компетенція) - потенційна дія, актуалізована в певній професійній ситуації. Компетенція є сукупністю знань, умінь, навиків, способів діяльності, тобто компонентів вмісту освіти, необхідних для ефективного виконання діяльності по відношенню до певного кола предметів і процесів. Поняття професійної компетентності включає не лише когнітивну і технологічну складові, але i мотиваційну, етичну, соціальну іповедінкову, тобто компетентність має завжди враховувати особистісні якості конкретної людини. Такий підхіду вищій професійній освіті дозволяє формувати ключові (базові, універсальні) і професійні компетенції, тобто готовність випускників використовувати засвоєні в додипломній освіті фундаментальні знання, уміння і навички, а також способи діяльності для вирішення практичних і теоретичних проблем, що виникають у процесі їх професійної діяльності. При організації освітнього процесу в руслі ідей модернізації професійної підготовки 3 дитячої хірургії необхідною умовою виступають до- 
мінування дослідницьких методів навчання, організація творчої діяльності, направленої на оригінальне мислення і нестандартне вирішення професійних завдань; саморозвиток студента як суб' єкта освітньої, творчої і професійної діяльності, мотивація інтелектуальних досягнень, розвиток аналітико-діагностичних умінь, прогноз професійних дій. Професійні компетенції в медицині - це перш за все робота біля ліжка хворого.

Особливе місце в підготовці сімейного лікаря з розділу дитячої хірургії ми відводимо впровадженню в освітній процес інтерактивних освітніх технологій, що сприяють формуванню елементів інноваційного потенціалу особи, таких, як ініціативність, прагнення до якісного виконання роботи, професійна компетентність, нестандартне мислення, прагнення до професійного зростання. Інноваційне навчання на кафедрі включає читання лекцій з мультимедійним супроводом, проведення практичних занять із використанням фантомів, тренажерів, тренінгових і контролюючих комп'ютерних програм. Реалізація такої моделі освіти при освоєнні курсу дитячої хірургії здійснюється шляхом системи ресурсно-орієнтованого навчання. Ця система передбачає використання технологій інтерактивного навчання. Перш за все це діалогове навчання - активне спілкування викладача та студента, студентів між собою, студентів із батьками хворої дитини або із хворою дитиною. В поняття інтерактивного навчання також вкладаємо вирішення типових і проблемних ситуаційних завдань, проведення “мозкових атак”, “круглих столів”, ділових і ролевих ігор, використання кейс-технологій.

Це дає можливість спільного, демократичного вирішення основних питань, що винесені на практичні і семінарські заняття, і таким чином закласти основи клінічного мислення та прийняття адекватного рішення щодо діагностики та лікування тої чи іншої хірур-

\section{Література}

1. Крицький І. О. Запровадження кредитно-модульної системи у практику роботи медичного факультету ТДМУ / I. О. Крицький, П. В. Гощинський, Г. А. Крицька // Медична освіта. - 2012. - № 4. - С. 18-19.

2. Осійчук М. С. Вплив євроінтеграційних процесів на розвиток вищої освіти / М. С. Осійчук // Кредитно-модульна система організації навчального процесу у вищих (фармацевтичному) навчальних закладах України на новому гічної патології дитини, активізувати пізнавальну діяльність студентів, освоєння ними прийомів майбутньої професійної діяльності та набуття умінь ставити завдання і знаходити шляхи їх вирішення.

У цьому плані багато уваги приділяється самостійній роботі студентів, які щодня присутні на ранішніх лікарських конференціях, де заслуховуються звіти чергових хірургів про виконану роботу i лікарську тактику, обговорюються важкі хворі, вирішуються конкретні ситуації. Найбільш складні хворі і принципові з етичної точки зору питання обговорюються після лікарської конференції в навчальній кімнаті з викладачем.

Слід зазначити, що додатковою ланкою до всіх вказаних вище етапів навчання дитячої хірургії є можливість, завдяки єдиній університетській телекомунікаційній системі, отримати on line зображення з операційних, навчальних кімнат, лекційних аудиторій, iз організованих онлайн-конференцій, семінарів і вебсемінарів, вступити в активний діалог із діючими особами. Це дає можливість наситити практичне або семінарське заняття додатковою сучасною науковою інформацією та “оживити” їх проведення.

Неоцінимий вкладупрактичну підготовку майбутніх сімейних лікарів вносить відпрацювання практичних навичок в університетському міжкафедральному фантомному центрі. Рівень засвоєння цих практичних навичок оцінюється шляхом складання об' єктивного структурованого клінічного іспиту (ОСКI) у кінці 5 та 6 курсів.

Висновок. Таким чином, впровадження нових технологій у навчальний процес дозволяє студентам старших курсів краще орієнтуватись в основній хірургічній патології дитячого віку, розвивати клінічне мислення, самостійно вирішувати клінічні питання, максимально наближені до реалій роботи сімейного лікаря.

етапі : матеріали X ювілейної Всеукр. навч.-наук. конф. 3 міжнар. участю (Тернопіль, 18-19 квітня 2013) : у 2 ч. Тернопіль, 2013. - С. 6-10.

3. Підготовка сімейних лікарів на сучасному етапі: вирішені та невирішені проблеми / Г. І. Лисенко, О. Б. Яценко, Л.В.Хіміон [та ін.] // Сімейна медицина. - 2011. - № 3. C. 5-6. 